\title{
A study of levothyroxine substitution therapy on subclinical hypothyroid patients and its effects on lipid profile in the department of medicine at tertiary care hospital
}

\author{
Raut $\mathrm{B}^{1}$, Paudel $\mathrm{N}^{2}$, Bhosekar $\mathrm{N}^{3}$ \\ ${ }^{1}$ Department of Pharmacology, Kathmandu Medical College and Teaching Hospital (KMCTH), Duwakot, \\ Bhaktapur, Nepal. ${ }^{2}$ Department of Internal Medicine, Kathmandu Medical College and Teaching Hospital \\ (KMCTH), Sinamangal, Kathmandu, Nepal. ${ }^{3}$ Department of Pharmacology, Kathmandu Medical College \\ and Teaching Hospital (KMCTH), Duwakot, Bhaktapur, Nepal.
}

\begin{abstract}
Background: Subclinical hypothyroidism is represented by high serum thyroid stimulating hormone (TSH) and normal serum free T4 and T3, Recent studies on subclinical hypothyroidism and lipid profile indicates that the serum total cholesterol, LDL-C, and total triglycerides were significantly increased. Clinical evidence suggests that thyroid replacement therapy with levothyroxine has beneficial effect. Methods: It is a hospital based prospective observational study involving 122 patients based on non probability sampling conducted in the Department of Internal Medicine. The study involved patients who have been diagnosed with subclinical hypothyroidism with normal level of free T4, T3 and elevated levels of TSH with positive Thyroperoxidase (TPO) antibodies. Patients were advised to investigate lipid profile before and afterprescribing levothyroxine. Follow up was done after 6-9 wks. Results: In this study 122 patients diagnosed with Subclinical hypothyroidism were prescribed with levothyroxine in which 112 came for follow up. The mean age of the patient was 46.81.There was significant reduction in mean TSH from $12.09( \pm 1.89) \mathrm{mIU} / \mathrm{L}$ to $7.97( \pm 1.59) \mathrm{mIU} / \mathrm{L}, \mathrm{TC}$ from $217.12( \pm 20.87) \mathrm{mg} / \mathrm{dl}$ to $198.47( \pm 17.34) \mathrm{mg} / \mathrm{dl}$ and LDL from $137.16( \pm 14.57) \mathrm{mg} / \mathrm{dl}$ to $124.62( \pm 12.89) \mathrm{mg} / \mathrm{dl}$ was found along with significant reduction in VLDL wasfound after levothyroxine therapy, There was slight reduction in serum triglyceride was found with no significant alteration in HDL and BMIlevels. Conclusion: The study showed significant reduction in the lipid profile including TC, LDL and VLDL after levothyroxine therapy. There was significant reduction in the level of TSHwas also found whereas the level of free T4 and T3 were not muchaltered. Therewas no significant change found in the level of HDLand BMI.
\end{abstract}

Keywords: Dyslipidemia, Levothyroxine, Subclinical hypothyroidism, Total cholesterol

\section{Introduction}

Iodine deficiency is one of the major public health problems with $30 \%$ prevalence of thyroid dysfunction in which $10 \%-17 \%$ of the population are suffering from subclinical hypothyroidism in Nepal. ${ }^{1}$ Subclinical hypothyroidism (SCH) is represented by high levels of serum thyroid stimulating hormone (TSH) concentration and normal serum total or free thyroxine (T4) and

Correspondence Author

Dr. Binod Raut, Assistant Professor

Kathmandu Medical College and Teaching Hospital (KMCTH),

Duwakot, Bhaktapur, Nepal

E-mail: binod14raut@gmail.com

Phone:+9779840050194 triiodothyronine (T3) with few orwithout any clinical sign and symptoms of hypothyroidism. It is more common in elderly people in which females are predominant than males. ${ }^{2}$

Thyroid dysfunction increases the lipid levels in which patients with TSH values between 5.1 - $10 \mathrm{mIU} / \mathrm{L}$ have significantly higher mean total cholesterol (TC) and low-density lipoproteincholesterol (LDL-C) levels. TSH was found to be high in $5.2 \%$ of the $49.5 \%$ of patients who were diagnosed with hyperlipidemia.3Some studies suggest that even subclinical hypothyroidism (SCH) might be the cause of hyperlipidemia 
and later linked to coronary heart diseases. In hypothyroidism, the dyslipidemia occurs due to increased synthesis and over degradation rate leading to raised levels of TC, LDL-C, and reactive oxygen species causing lipid peroxidation leading to oxidative stress. ${ }^{4}$

The coexistence between dyslipidemia and hypothyroidism has become one of the main risk factors for the development of atherosclerosis ,which occurs due to changes in lipid profile, arterial hypertension, inflammation and oxidative stress leading to endothelial dysfunction which is the major cause of death due to development of coronary heart diseases. ${ }^{5,6}$ A TSH value above $2.5 \mathrm{mIU} / \mathrm{L}$ in women of child bearing age may induce oxidative damage to membrane lipids and alter the lipid profile, suggesting that TSH levels should be maintained below this value, similarly above $10 \mathrm{mIU} / \mathrm{L}$ can be considered as predictor of cardiovascular disease since lipid status worsens along with TSH levels.7Recent studies on subclinical hypothyroidism and lipid profile indicates that the serum total cholesterol, LDL-C, and total triglycerides were significantly increased in $\mathrm{SCH}$ patients. ${ }^{8}$

Levothyroxine administration to normalize the lipid profile of subclinical hypothyroidism patients depends upon the degree of disease progression and has shown its proven efficacy in reducing TC and LDL-C with TSH value $<10$ $\mathrm{mIU} / \mathrm{L}$.9levothyoxine replacement in $\mathrm{SCH}$ patients has shown significant improvement in both lipid profile and the carotid artery intima-thickness : a well recognized index of early atherosclerosis and cardiovascular events along with significant reduction in serum TC and LDL-C levels by 5.5 and $7.3 \%$ respectively.10studies conducted in Nepal had also suggested that hypothyroidism is more prevalent which lead to elevated level of cholesterol and subclinical hypothyroidism which is one of the important risk factor for causing cardiovascular disease so its earliest prevention is utmost requirement. ${ }^{11}$
The aim of the present study is to observe the effect of levothyroxine substitution therapy on serum lipid profile in patients diagnosed with subclinical hypothyroidism at tertiary care hospital.

\section{Methods}

The prospective observational study involving 122 patients based on non-probability sampling was conducted in the Department of Internal Medicine of Tertiary care Teaching Hospital from July 2019 to March 2020 after obtaining ethical approval from institutional ethical committee. The study involved patients who have been diagnosed with subclinical hypothyroidism with normal level of free thyroxine (T4), Triiodothyronine (T3) and elevated levels of Thyroid Stimulating Hormone (TSH) with positive Thyroperoxidase (TPO) antibodies. Patients were advised to investigate lipid profile which includes Serum Triglyceride (STG), Total Cholesterol (TC), Low Density Lipid Cholesterol (LDL-C), Very Low-Density Lipid cholesterol (VLDL-C), and High Density Lipid (HDL). Height and weight were also recorded for BMI scale and obesity.

Patients were prescribed with levothyroxine tablet 50,75 and 100 micrograms once a day on the basis of TSH levels. Follow up was done after 6-9 wks and again Thyroid level test andlipid profile test along BMI of the patient were recorded and the difference in the value of Thyroid level, BMI and Lipid level were compared before and after levothyroxine therapy.

Data has been recorded in customized proforma from the patient record sheets and reports during the outpatient follow up after taking consent from the patient. All the collected data were retrieved from proforma and the statistical program for the social sciences (SPSS) package version 20 was used for analysis.

\section{Results}

Among 122 diagnosed patients with subclinical hypothyroidism only 112 patients visited for follow up. The age of the patient in this study ranges from minimum 23 years to maximum 73 years with 
mean age of 46.81( $( \pm 12.02)$ The level of BMI was $18.50 \mathrm{~kg} / \mathrm{m} 2$ to $38.0 \mathrm{~kg} / \mathrm{m} 2$ with mean value of $27.85 \mathrm{~kg} /$ $\mathrm{m} 2$ similarly the level of TSH was $8.25 \mathrm{mIU} / 1$ to $15.90 \mathrm{mIU} / 1$ with mean value of $11.90 \mathrm{mIU} / 1$. The level of free T4 was $6.25 \mu \mathrm{g} / \mathrm{dl}$ to $11.05 \mu \mathrm{g} / \mathrm{dl}$ with mean value of $8.61 \mu \mathrm{g} / \mathrm{dl}$ and the level of T3 was $1.78 \mathrm{ng} / \mathrm{dl}$ to $7.42 \mathrm{ng} / \mathrm{dl}$ with mean value of $4.30 \mathrm{ng} / \mathrm{dl}$. The lipid levels were recorded after diagnosis with sub clinical hypothyroidism. Serum Triglyceride was $140 \mathrm{mg} / \mathrm{dl}$ to $250 \mathrm{mg} / \mathrm{dl}$ with the mean value of $196.56 \mathrm{mg} / \mathrm{dL}$, the value of TC was $178 \mathrm{mg} / \mathrm{dl}$ to $285 \mathrm{mg} / \mathrm{dl}$ with mean value of $215.45 \mathrm{mg} / \mathrm{dl}$. The level of LDL-C was 94.68 $\mathrm{mg} / \mathrm{dl}$ to $167.80 \mathrm{mg} / \mathrm{dl}$ with mean value of $134.23 \mathrm{mg} / \mathrm{dl}$, the level of VLDL-C was $20.82 \mathrm{mg} / \mathrm{dl}$ to 55.42 $\mathrm{mg} / \mathrm{dl}$ with mean value of $35.17 \mathrm{mg} / \mathrm{dl}$ and the value of HDL was $36 \mathrm{mg} / \mathrm{dl}$ to $47 \mathrm{mg} / \mathrm{dl}$ with mean value of $42.08 \mathrm{mg} / \mathrm{dl}$.

Table :1 Descriptive parameters before Levothyroxine Therapy:

\begin{tabular}{|l|l|l|l|l|l|}
\hline & Number & Minimum & Maximum & Mean & Std. Deviation \\
\hline Age & 122 & 23 & 73 & 46.81 & 12.020 \\
\hline BMI before & 122 & 18.50 & 38.00 & 27.85 & 3.601 \\
\hline TSH before & 122 & 8.25 & 15.90 & 11.90 & 1.943 \\
\hline T3 before & 122 & 1.780 & 7.42 & 4.30 & 1.22 \\
\hline T4 before & 122 & 6.25 & 11.05 & 8.61 & .999 \\
\hline TC before & 122 & 178 & 285 & 215.45 & 20.949 \\
\hline TG before & 122 & 140 & 250 & 196.56 & 23.067 \\
\hline LDL-c before & 122 & 94.68 & 167.80 & 134.23 & 17.166 \\
\hline VLDL-c before & 122 & 20.82 & 55.42 & 35.17 & 8.082 \\
\hline HDL-c before & 122 & 36 & 47 & 42.08 & 2.031 \\
\hline
\end{tabular}

Mean BMI of the patients before therapy was 27.85 $\mathrm{kg} / \mathrm{m} 2$ which was found to be $28.21 \mathrm{~kg} / \mathrm{m} 2$ after therapy, there was no significant difference in the mean value of BMI before and after therapy.

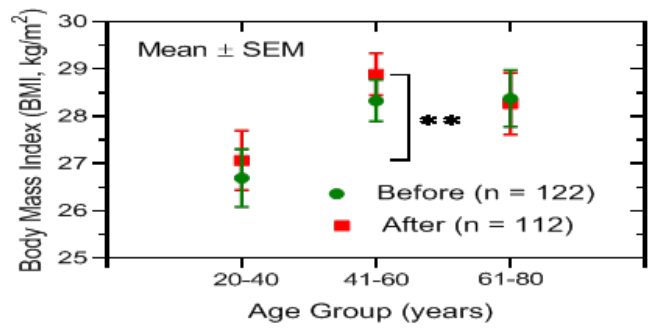

Figure 1: Age-wise BMI distribution before and after Levothyroxine therapy
Paired T-test was applied for the comparison of various parameters of thyroid and lipid profile before and after levothyroxine therapy. Mean value of TSH was found to be $7.91 \mathrm{mIU} / \mathrm{L}$ with SD \pm 1.59 . Mean value of $\mathrm{T} 4$ was found to be $7.11 \mu \mathrm{g} /$ dl with $\mathrm{SD} \pm 1.16$ similarly mean value of $\mathrm{T} 3$ was $3.58 \mathrm{ng} / \mathrm{dl}$ with $\mathrm{SD} \pm .732$. The mean value of STG was found to be $195.6 \mathrm{mg} / \mathrm{dl}$, the mean value of TC was found to be $198.47 \mathrm{mg} / \mathrm{dl}$, LDL-C was found to be with mean value of $124.62 \mathrm{mg} / \mathrm{dl}$, VLDL-C was found to be $29.93 \mathrm{mg} / \mathrm{dl}$ and the mean value of HDL was found to be $41.15 \mathrm{mg} / \mathrm{dl}$. 
Table 2: Thyroid parameters before and after Levothyroxine therapy

\begin{tabular}{|l|l|l|l|l|}
\hline $\begin{array}{c}\text { Thyroid } \\
\text { parameters }\end{array}$ & $\begin{array}{c}\text { Before therapy } \\
\text { Mean } \pm \text { S.D. }(\mathbf{n = 1 2 2})\end{array}$ & $\begin{array}{c}\text { After therapy } \\
\text { Mean } \pm \text { S.D.(n=112) }\end{array}$ & correlation & P - value \\
\hline $\mathrm{TSH}(\mathrm{mIU} / \mathrm{L})$ & $12.09 \pm 1.89$ & $7.97 \pm 1.59$ & .680 & $<0.001$ \\
\hline $\mathrm{T} 4(\mu \mathrm{g} / \mathrm{dL})$ & $8.63 \pm 1.01$ & $7.11 \pm 1.16$ & .326 & $<0.001$ \\
\hline $\mathrm{T} 3(\mathrm{ng} / \mathrm{dL})$ & $4.46 \pm 1.14$ & $3.58 \pm .732$ & .743 & $<0.001$ \\
\hline
\end{tabular}

The mean value of TSH was higher in $\mathrm{SCH}$ patients $11.90 \mathrm{mIU} / \mathrm{L}$ before levothyroxine therapy which was found to be $7.91 \mathrm{mUI} / \mathrm{L}$ after therapy which was statistically significant shown in below with figure.

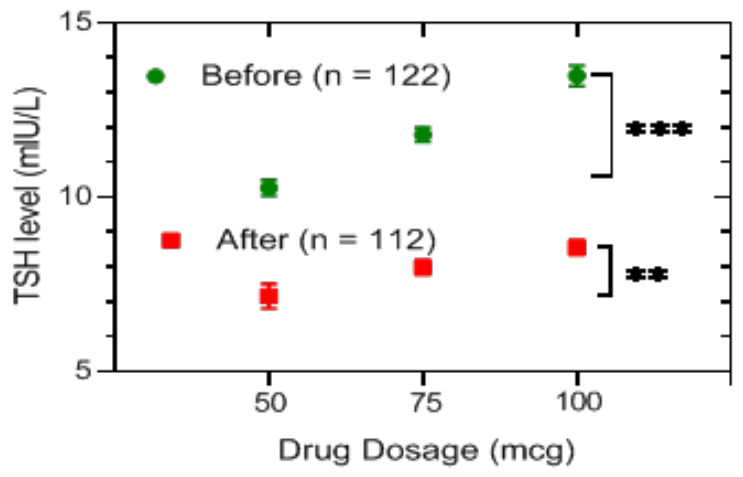

Figure: 2 Distribution of TSH value before and after Levothyroxine Therapy
The mean level of STG was 199.11 $( \pm 21.93) \mathrm{mg} /$ dL when compared to patients after therapy it was 195.56( \pm 23.23$) \mathrm{mg} / \mathrm{dl}$ (p: 0.001).The level of Total cholesterol was even markedly higher in patients before therapy which was $217.12( \pm 20.87) \mathrm{mg} / \mathrm{dl}$ which was found to be $198.47( \pm 17.34) \mathrm{mg} / \mathrm{dl}(\mathrm{p}$ : 0.001). The mean LDL levels were significantly higher before therapy $137.16( \pm 14.57) \mathrm{mg} / \mathrm{dl}$ compared to patients after therapy was 124.62 $( \pm 12.89) \mathrm{mg} / \mathrm{dl}$. Similarly the mean value of VLDL was $35.98( \pm 7.89) \mathrm{mg} / \mathrm{dl}$ before and it was found to be $29.93( \pm 7.89) \mathrm{mg} / \mathrm{dl}$ after therapy. The mean HDL was higher in patients with $\mathrm{SCH}$ before therapy $42.32( \pm 1.89) \mathrm{mg} / \mathrm{dl}$ compared to patients after therapy $41.15( \pm 1.80) \mathrm{mg} / \mathrm{dl}$ which was not statistically significant.

Table 3: Lipid parameters before and after Levothyroxine therapy

\begin{tabular}{|l|l|l|l|l|}
\hline $\begin{array}{c}\text { Lipid parameters } \\
(\mathbf{m g} / \mathbf{d L})\end{array}$ & $\begin{array}{c}\text { Before therapy } \\
\text { Mean } \pm \text { S.D.(n=122) }\end{array}$ & $\begin{array}{c}\text { After therapy } \\
\text { Mean } \pm \text { S.D.(n=112) }\end{array}$ & correlation & P-value \\
\hline SerumTriglyceride & $199.11 \pm 21.93$ & $195.56 \pm 23.23$ & .720 & $<0.001$ \\
\hline Total cholesterol & $217.12 \pm 20.87$ & $198.47 \pm 17.34$ & .834 & $<0.001$ \\
\hline LDL-cholesterol & $137.16 \pm 14.57$ & $124.62 \pm 12.89$ & .833 & $<0.001$ \\
\hline VLDL-cholesterol & $35.98 \pm 7.89$ & $29.93 \pm 6.14$ & .857 & $<0.001$ \\
\hline HDL- cholesterol & $42.32 \pm 1.89$ & $41.15 \pm 1.80$ & .509 & $<0.001$ \\
\hline
\end{tabular}

The mean value of total cholesterol (TC) was 217.12 $( \pm 20.87) \mathrm{mg} / \mathrm{dl}$ before therapy and was found to be $198.47( \pm 17.34) \mathrm{mg} / \mathrm{dl}$ after therapy similarly the mean vale of LDL_C was137.16 $( \pm 14.57) \mathrm{mg} / \mathrm{dl}$ before and it was found to be $124.62( \pm 12.89) \mathrm{mg} /$ $\mathrm{dl}$ after therapy which was statistically significant shown below with figure. 

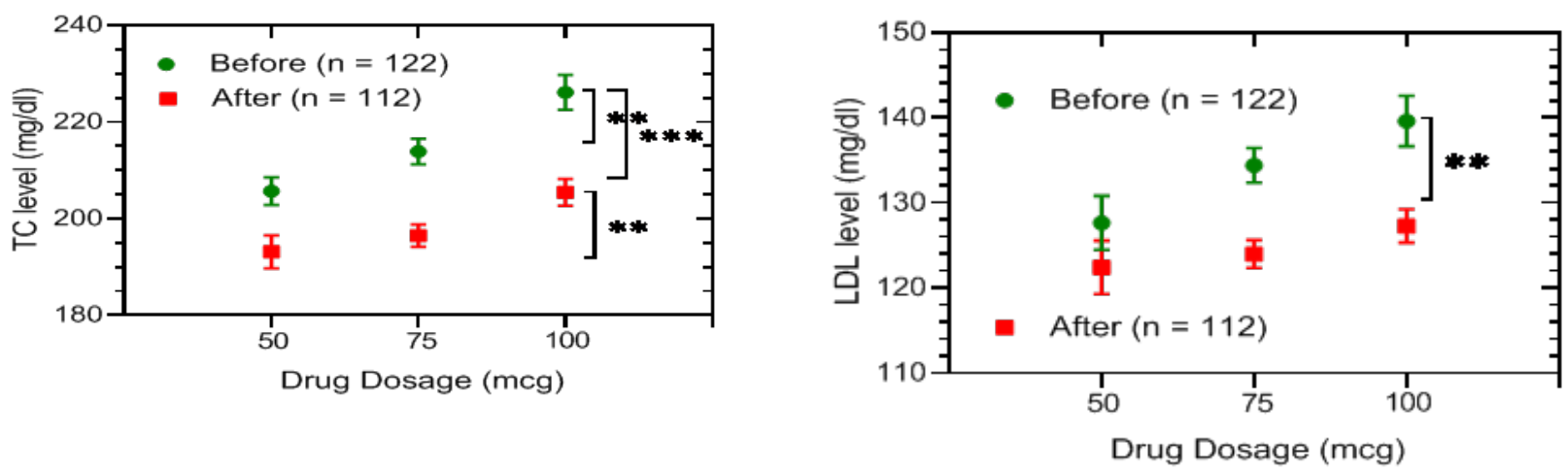

Figure: 3 Alterations in TC and LDL_C after Levothyroxine therapy

\section{Discussion}

Thyroid disorders are the most common endocrine disorders and these have major role in the alteration of lipid metabolism. Hypothyroidism is one of the most common ailment affecting patients attending endocrine outpatient department. Increase in the level of TSH is the key finding for early detection of thyroid dysfunction. Out of 122 diagnosed $\mathrm{SCH}$ patients 112 patients came for follow up after prescribing levothyroxine.

In the present study a predominance of female was noted in which F: M ratio is 3:1.similar other studies also reported that hypothyroidism was more prevalent among females than male. ${ }^{12}$ The mean age of the patient in this study was 46.81 which is almost similar to the study done by Ravisekher et al with the mean age of $50.20 \mathrm{yrs}$ in male and 48.02 years in female. ${ }^{13}$

In the present study an evaluation regarding BMI was also undertaken which was recorded based on weight on kilogram and height on meter square, the mean BMI of the patient was found to be $27.85 \mathrm{~kg} /$ $\mathrm{m}^{2}$ in the similar study they have observed BMI of $28.1 \mathrm{~kg} / \mathrm{m} 2,{ }^{14}$ similar study conducted in Tehran has observed the level of BMI was $26.3 \mathrm{~kg} / \mathrm{m}^{2}$. In our study we found no significant alteration in BMI after therapy it was $27.85 \mathrm{~kg} / \mathrm{m}^{2}$ to $28.21 \mathrm{~kg} / \mathrm{m} 2$.Another study has also revealed there was no change in BMI after levothyroxine therapy the probable reason behind this alteration in BMI is most probably due to the fact that patient were not advised to reduce the dietary intake and change in the lifestyle which supported our study. ${ }^{15}$

In this study it was found that there was raised level of TSH whose mean value was $11.90 \mathrm{mIU} / \mathrm{L}$ which suggest that levothyroxine therapy was required whereas the level of free T4 and T3 was in the range of mean value with $8.63 \mathrm{mIU} / \mathrm{L}$, and $4.46 \mathrm{mIU} / \mathrm{L}$ which was in within the normal range there was significant reduction in TSH value was found after prescribing levothyroxine. The value of TSH was $7.97 \mathrm{mIU} / \mathrm{L}$, similarly there was slight reduction of mean value of free T4 and T3 was there which was $7.11 \mathrm{mIU} / \mathrm{L}$, and $3.58 \mathrm{mIU} / \mathrm{L}$. These findings were similar to the study confirmed by a recent, randomized, double blind, crossover trial in patients having $\mathrm{SCH}$ with a mean TSH of $6.6 \mathrm{mIU} / \mathrm{L}$, which showed that levothyroxine treatment leads to significant improvement in many cardiovascular risk factors including total and LDL cholesterol [Razvi et al. 2007] ${ }^{10}$

In our study it was found that there was raised level of serum triglyceride, total cholesterol and Low density lipoprotein cholesterol and very low density lipoprotein which signifies the condition of hypothyroidism causing rise in circulating cholesterol similar studies done by Pearce et al observed increased in serum triglyceride, total cholesterol, low density lipoprotein (LDL) cholesterol in subclinical hypothyroid patients which supports our findings, the reason behind the increment in the total cholesterol and LDL 
cholesterol levels may be due to formation of oxidized LDL cholesterol leading to enhanced risk of atherosclerosis. ${ }^{16}$ Another recent study has suggested that dyslipidemia was more in patients with $\mathrm{SCH}$, and the levels of Total cholesterol, STG and LDL- $\mathrm{C}$ were also significantly high whereas HDL-C levels were lower compared to the control group. ${ }^{17}$

Serum triglyceride levels were also significantly high in our study Carontein et al also observed higher mean level of serum triglyceride with lower mean level of HDL levels in sub clinical hypothyroid patients .it also suggest that particularly in patient with subclinical hypothyroid there was marked raised value of STG, TC, LDL-C and VLDL-C with reduced level of HDL which has direct role in the development of complication in the formation of atherosclerosis and other cardiovascular diseases. ${ }^{18}$ In our study the doses of levothyroxine has been prescribed based on the level of TSH from 50 microgram, 75 microgram to 100 microgram once a day and patient has been reviewed for follow up after 6-9 wks duration similar studies also suggests The ETA guidelines recommend a weight-adjusted starting dose of $1.5 \mu \mathrm{g} / \mathrm{kg}$ daily (e.g. 100 or 125 $\mu \mathrm{g} / \mathrm{daily}$ for a man, 75 or $100 \mu \mathrm{g}$ for woman) for patients without cardiac disease and 25-50 $\mu \mathrm{g}$ daily for patients having heart problems and in the elderly. ${ }^{16}$ The serum TSH should be rechecked 2-3 months after starting levothyroxine with the aim of keeping TSH in the lower half of recommended range $(0.4-2.5 \mathrm{mIU} / \mathrm{l})$, though a higher reference range $(1.0-5.0 \mathrm{mIU} / \mathrm{l})$ is acceptable in elderly patients (>70 years) [Biondi and Cooper, 2008]. ${ }^{19}$ Another study has also concluded the decrease in the TSH level from mean $( \pm \mathrm{SD}) 6.40 \pm 2.01 \mathrm{mIU} / \mathrm{L}$ to $3.63 \mathrm{mIU} / \mathrm{L}$ at the median dose of 50 micro gram of levothyroxine, it was mentioned that the study was underpowered to detect any effect on the incidence of cardiovascular events and mortality. ${ }^{20}$ In our study it was found that there was significant decrease in the mean level of STG, TC, LDL-C and VLDL-C with less significant alteration in the level of HDL after replacement therapy with levothyroxine, similar studies has supported our findings in which it was clearly mentioned that after replacement therapy with levothyroxine in sub clinical hypothyroid patient there was marked reduction in STG, TC and LDL was observed which has direct role in avoiding incidence of CAD, stroke and peripheral vascular disease. ${ }^{21}$ various other studies had also revealed the fact that there was significant reduction of total cholesterol and LDL cholesterol following levothyroxine therapy which also support our observations..$^{22}$ Monzane et al 23 also found reduction in level of STG after replacement therapy which has similar result that support our study but few studies has contradictory result in respect to STG value Ineck et al did not observed any significant change in the value of STG level following levothyroxine therapy. ${ }^{24}$ It has been suggested in a recent Cochrane systematic review that thyroxine treatment in patients with $\mathrm{SCH}$ improved cardiovascular risk in terms of reducing serum cholesterol and improved cardiac function. But due to insufficient data, no clear recommendations could be stated and it was suggested that the decision either to treat or not should be on an individual basis Villar et al. 2007. ${ }^{25}$ In another randomized trials which evaluate the effect of levothyroxine therapy in patients having mild $\mathrm{SCH}$ are considered insufficient to support levothyroxine treatment in this group and the benefits seen in the available trials are either very minor or of no benefit. ${ }^{26}$

In our study there was statistical significant decrease in STG was observed before and after levothyroxine therapy in which STG has decrease from $199.11 \mathrm{mg} / \mathrm{dl}$ to $195.56 \mathrm{mg} / \mathrm{dl}$. Similarly the mean value of total cholesterol has reduced from $217.12 \mathrm{mg} / \mathrm{dl}$ to 198.47 , LDL-C has reduced from $137.16 \mathrm{mg} / \mathrm{dl}$ to $124.62 \mathrm{mg} / \mathrm{dl}$ and VLDL from $35.98 \mathrm{mg} / \mathrm{dl}$ to $29.96 \mathrm{mg} / \mathrm{dl}$, but there was reduction in the level of HDL from $42.32 \mathrm{mg} / \mathrm{dl}$ to $41.15 \mathrm{mg}$ / dl similar studies also supported our finding in which Monzani et al reported that replacement with levothyroxine in $\mathrm{SCH}$ patients significantly reduced both total cholesterol $(214.2 \pm 37.5 \mathrm{mg} / \mathrm{dL} \mathrm{Vs} 191.6$ $3 \pm 2.5 \mathrm{mg} / \mathrm{dL}$ ), and LDL cholesterol (138.9 \pm $32.3 \mathrm{mg} / \mathrm{dL}$ Vs $119.2 \pm 27.8 \mathrm{mg} / \mathrm{dL}$ ). There was a 
reduction in the levels of triglycerides $(94.0 \pm 31.9$ $\mathrm{mg} / \mathrm{dL}$ Vs $88.1 \pm 30 \mathrm{mg} / \mathrm{dL}$ ) as well, these findings supported our observations. ${ }^{23}$ In contrast to our findings, Efstathidou et al observed no significant changes in serum lipid profiles after levothyroxine therapy except for a decrease in HDL-cholesterol $(59 \pm 15$ to $55 \pm 14 \mathrm{mg} / \mathrm{dL}, \mathrm{p}<0.05){ }^{3}$

\section{Conclusion}

In conclusion this study has concluded that the prevalence of subclinical hypothyroidism is high and earliest management of raised level of thyroid stimulating hormone (TSH) is utmost important. Replacement therapy done by the levothyroxine has direct effect on reducing total cholesterol (TC) and low density lipoprotein cholesterol (LDL-C) and it has also effective role in reducing serum triglyceride (STG) and very low density lipoprotein cholesterol (VLDL-C). It has no significant effect regarding body mass index (BMI) and high density lipoprotein (HDL).

\section{Recommendation}

Dyslipidemia and its effects on cardiovascular system including ischemic heart disease, heart failure, stroke and peripheral vascular disease leading to increase in the mortality implies that earliest management of sub clinical hypothyroidism can prevent the alteration in the lipid levels and further control the cardiovascular complications. Therefore biochemical screening of thyroid dysfunction is recommended for the early diagnosis of dyslipidemia and sub clinical hypothyroidism.

levothyroxine replacement therapy has important role in the improvement of quality of life and prevention of cardiovascular diseases related complications by controlling the thyroid stimulating hormone levels and lipid levels.

\section{Refferences}

1. Nepal AK, Shakya PR, Gelal B, Lamsal M, Brodie DA and Baral N. Household Salt Iodine Content Estimation with the Use of Rapid Test Kits and Iodometric Titration Methods. J ClinDiagn Res 2013;7(5):892-8 PMID:
23814736PMCID: PMC3681063DOI: 10.7860/ JCDR/2013/5477.2969

2. Drover VA, Agellon LB. Regulation of the human cholesterol 7alpha-hydroxylase gene (CYP7A1) by thyroid hormone in transgenic mice. Endocrinology 2004;145:574-581. PMID: 14592954DOI: 10.1210/en.2003-0993.

3. Willard DL, Leung AM, Pearce EN. Thyroid function testing in patients with newly diagnosed hyperlipidemia. JAMA Intern Med. (2014) 174:287-9. doi: 10.1001/ jamainternmed.2013.12188.

4. Duntas LH. Thyroid disease and lipids. Thyroid (2002) 12:287-93. doi: 1089/1050725025294940.

5. Gobal FA, Mehta JL. Management of dyslipidemia in the elderly population. TherAdvCardiovasc Dis. (2010) 4:375-83. doi: $10.1177 / 1753944710385048$

6. Delitala AP, Fanciulli G, Maioli M, Delitala G. Subclinical hypothyroidism, lipid metabolism and cardiovascular disease. Eur $\mathrm{J}$ Intern Med. (2017) 38:17-24. doi: 10.1016/j. ejim.2016.12.015

7. Karbownik-Lewinska M, Marcinkowska M, Stepniak J, Lewinski A. TSH $\geq 2.5 \mathrm{mIU} / 1$ is associated with the increased oxidative damage to membrane lipids in women of childbearing age with normal thyroid tests. HormMetab Res. (2017) 49:321-6. doi: 10.1055/s-0042-120712

8. Liu XL, He S, Zhang SF, Wang J, Sun XF, Gong CM, et al. Alteration of lipid profile in subclinical hypothyroidism: a meta-analysis. Med SciMonit 2014;20: 1432-1441. PMID: 25124461,doi : 10.12659/MSM.891163

9. Li X, Wang Y, Guan Q, Zhao J, Gao L. The lipid-lowering effect of levothyroxine in patients with subclinical hypothyroidism: a systematic review and meta-analysis of randomized controlled trials. ClinEndocrinol. (2017) 87:1-9. doi: 10.1111/cen.13338

10. Razvi S, Ingoe L, Keeka G, et al. The beneficial effect of 1-thyroxine on cardiovascular risk factors, endothelial function, and quality of life in subclinical hypothyroidism: randomized, crossover trial. J ClinEndocrinolMetab. 
2007;92:1715-1723. [PubMed] [Google Scholar]

11. Risal P1, Maharjan BR1, Koju R2, Makaju RK3, Gautam M4. Kathmandu University Medical Journal (2010), Vol. 8, No. 2, Issue 30, 265-268. doi.org/10.3126/kumj.v8i2.3573

12. Mayer O, Simon J, Filipovsky J, et al. Hypothyroidism in coronary heart disease and its relation to selected risk factors. Vasc Health Risk Manag. 2006;2(4):499-506.doi: 10.2147/ vhrm.2006.2.4.499

13. Shekhar R, Chowdary NVS, Das MC, et al. Prevalence of subclinical hypothyroidism in coastal Andhra Pradesh. Biomed Res. 2011;22(4):471-4.

14. Efstathiadou Z, Bitsis S, Milionis HJ, et al. Lipid profile in subclinical hypothyroidism: is L- thyroxine substitution beneficial. Eur J Endocrinol. 2001;145(6):705-10. DOI: 10.1530/eje.0.1450705

15. Lomenick JP, El-Sayyid M, Smith WJ. Effect of L-thyroxine treatment on weight and body mass index in children with acquired hypothyroidism. J Pediatr. 2008;152:96100. PMID: 18154908DOI: 10.1016/j. jpeds.2007.06.006

16. Pearce, S., Brabant, G., Duntas, L., Monzani, F., Peeters, R., Razvi, S. et al. (2013) 2013 ETA guideline: management of subclinical hypothyroidism. Eur Thyroid J 2: 215-228. DOI: $10.1159 / 000356507$

17. Hussain A, Elmahdawi AM, Elzeraidi NE, Nouh F, Algathafi K. The Effects of Dyslipidemia in Subclinical Hypothyroidism. Cureus. 2019 Nov 16;11(11):e6173. doi: 10.7759/cureus.6173. PMID: 31890380; PMCID: PMC6913946.

18. Carantoni M, Vigna GB, Stucci N, et al. Low levels of HDL Cholesterol in hypothyroid patients with cardiovascular diseases. Minerva Endocrinol. 1997;22(4):91-7.PMID: 9586415

19. Biondi B, Cooper DS. The clinical significance of subclinical thyroid dysfunction. Endocr Rev. 2008;29(1):76-131. doi:10.1210/er.2006-0043

20. Stott DJ, Rodondi N, Kearney PM. Thyroid hormone therapy for older adults with subclinical hypothyroidism. N Engl J Med. 2017;376:2534-2544.doi: 10.1056/ NEJMoa1603825. [PubMed] [CrossRef] [Google Scholar]

21. Akbar DH, Ahmed MM, Hijazi NA. Subclinical hypothyroidism in elderly women attending an outpatient clinic. Med SciMonit. 2004;10(5):CR 229-32.PMID: 15114275

22. Helfand M, Redfern CC. Screening for thyroid disease: an update. Ann intern Med. 1998;129:144-58.doi: $\quad$ 10.7326/0003-4819129-2-199807150-00020.

23. Monzani F, Caraccio N, Kozakowa M, et al. Effect of levothyroxine replacement on lipid profile and intima media thickness in subclinical hypothyroidism : a double blind, placebocontrolled study. J ClinEndocrinolMetab. 2004;89(5):2099-106.doi: 10.1210/jc.2003031669.

24. Ineck BA, Ng TM. Effects of subclinical hypothyroidism and its treatment on serum lipids. Ann Pharmacothes. 2003;37(5):725-30. doi.org/10.1345/aph.1C376

25. Villar, H., Saconato, H., Valente, O. and Atallah, A. (2007) Thyroid hormone replacement for subclinical hypothyroidism. Cochrane Database Syst Rev: CD003419.doi: 10.1002/14651858.CD003419.pub2.

26. Baumgartner, C., Blum, M. and Rodondi, N. (2014) Subclinical hypothyroidism: summary of evidence in 2014. Swiss Med Wkly 144: w14058.doi: https://doi.org/10.4414/ smw.2014.14058. 